\title{
Islam and Politics \\ (Hurly-Burly of Religious Issues in the 2017 Jakarta Gubernatorial Election)
}

\author{
Hamdani Ph.D \\ Graduate Program of University of Nahdlatul Ulama Indonesia (UNUSIA) Jakarta, \\ Department of Social and Political Science (FISIP) \\ UIN Syarif Hidayatullah Jakarta, Indonesia. \\ hamdani@uinjkt.ac.id
}

\begin{abstract}
The rivalry among contesting political forces during the 2017 Gubernatorial Election has shown how religious issues have been used by certain agents to support and against their competitor. The Christian-Chinese governor, Basuki Tjahaya Purnama, who ran for the election was challenged by two Muslim candidates: Anies Rasyid Baswedan and Agus Harimurti Yudhoyono. During the political campaign, huge energy was empowered to influence the direction of politics either online or offline. The scale of rivalry was even beyond Jakarta. This study examines the religious discourse which emerged during the political campaign of the 2017 Jakarta governor election (Pilkada). The different interpretation of religious concepts such as fatwa (religious edict), kafir (Infidel) and munafik (double standard) among a certain group of Muslims have contributed a significant role in influencing voters in the regional election. While Indonesian Islam has been known as moderate, the recent political trend has shown an opposite inclination. The strengthening faction of conservatives and radicals in the political contestation has sparked a speculation among scholars concerning the waning of moderate Islam Nusantara. This study attempts to capture the pattern of religious movement of various agents of Muslim in the postSuharto era. Since Susilo Bambang Yudhoyono failed to maintain the politics of diversity (kebhinekaan) and anticipate radical movements, the pressure of conservative-Islamist in the 'Aksi Bela Islam' (Defending Islam Action) is a test whether Jokowi's administration capable of overcoming such challenges under the corridor of national laws and democratic principles.
\end{abstract}

Keywords - Religious discourse, fatwa, Pilkada, Moderate Muslims, Conservative and Islamist Groups.

\section{INTRODUCTION}

The involvement of religious issues and agents in the political game has been an important topic in the study of social and political sciences. In many political actions, religious issues often emerge or have been purposely involved by various actors to succeed their political agenda. Interestingly, the pattern of relations between religion and politics tends to vary from one case to another. In the current development of Indonesian experience during contestation of Jakarta gubernatorial election, the engagement of religious issues showed a surprising result. Through collaboration between political and Islamist agents, moderate and pluralist groups have been successfully pushed into a corner. This research focuses on three aspects: (1) identification of religious issues in the electoral politics of the 2017 Jakarta gubernatorial election, (2) capturing the rivalry between moderate and Islamist groups in the political game, and (3) probing the state policy on treatment of competing agents in the hurly-burly of political dispute.

\section{HURLY-BURLY OF 2017 JAKARTA GUBERNATORIAL ELECTION}

Many political observers argue that the 2017 gubernatorial contestation (Pilkada) was crueler than the 2012 election. When Jokowi and Ahok run for the 2012 gubernatorial election, religious and racial issues had emerged in the black campaign from their rival. However, those things did not significantly take effect to the Jakarta voters. It is different with the 2017 election when Ahok run for the gubernatorial election with his partner Djarot Saiful Hidayat against their competitor: Agus Harimurti Yudhoyono-Sylviana Murni and Anis Baswedan-Sandiaga Uno. In this election, political maneuver using religious sentiments was so strong that decision to vote based on religion was so dominant and took effect to the defeat of Ahok [1].

The wave of resistance to Ahok emerged since his statement was published by a social media user in an edited version. His concern to many Muslim preachers, who use the qur'anic verse of 'Al-Maidah 51' to attack him, was assumed and framed by his rival as the blasphemy. This opinion was formed among Islamist groups which, later on, staged serial demonstrations to put him in jail. Moreover, it was also supported by Indonesia Ulama Council (MUI) which issued a 'religious opinion' on the ban of Muslims to elect a nonMuslim leader. It is interesting that such a religious opinion was treated as 'fatwa' (formal religious edict) and inspired Muslim groups to defend it by erecting an ad-hoc organization called 'Gerakan Nasional Pengawal Fatwa MUI' (National Movement to defend the MUI's fatwa).

Since many Islamist groups have great access to Jakarta mosques, the theme of Friday Sermon and religious forum have been dominantly filled by the ban for Muslim to elect Ahok 
[2]. During the period of the campaign, I often purposely monitor some mosques to find out the content of sermons and discovered many preachers did not convey religious messages in a wise approach. They tend to present a single interpretation of the leader in Islamic perspective that electing a non-Muslim leader is unlawful deed (haram). At that time, it is only a few mosques delivering neutral messages to political dispute or in a moderate position.

The serious effort of Islamist groups to campaign against the aspiration to elect non-Muslim leader reached the level of religious and social exclusion when they labeled Muslims who stand for Ahok as 'kafir' (infidel) and 'munafik' (hypocrite). In Islamic teachings, these two concepts are very serious status referring to those who do not agree with Islam and evil, and those who betray Islamic principles. This label spread in social media and found printed on banners. As a result, it divided Muslim groups in a sharp opposition.

At the grass-root level, there was a threat from Islamist agents not to give religious service (funeral) for those who do not elect Muslim governor. This threat happened to an old woman, Hindun binti Raisman, who died and was not treated properly regarding religious and cultural habit. According to her daughter, Neneng, a local cleric (Ahmad Syafi'ie) who should organize communal prayer (salat jenazah) for her mother rejected to do it. She believed that such a rejection due to her mother political preference. When Hindun voted in the election, many people know that she voted for Ahok-Djarot [3].

\section{CONSERVATIVE VERSUS MODERATE GROUPS}

The inclination of Indonesian Muslim has been known as moderate, however, it has been confused by the growing trend of conservative and hardliner factions in the last few decades. The observation of scholars on this development has been presented in keywords such as 'conservative turn' [4] and 'deepening conservatism' [5] of the landscape of Indonesian Islam. Hardline factions of Muslim organizations have also taken a visible role in the forging of public issues which is represented by the Front Pembela Islam (FPI, Islamic Defence Front), Forum Umat Islam (FUI, Muslim Forum), Majelis Intelektual dan Ulama Muda Indonesia (MIUMI, Intellectual Forum and Indonesia Young Ulama), Hizbut Tahrir Indonesia (HTI), etc.

In the 2017 Jakarta gubernatorial election, the constellation of Muslim groups has been fractured, at least, into two factions: conservative and moderate groups. While conservative against Ahok-Djarot in an aggressive approach, moderate factions tended to be cautious responding the tension between two contestants. Apart from the online campaign, conservative groups mobilized mass in many demonstrations and religious-based movements. Their messages contain racial sentiment, anti-pluralism and anti-government. On the contrary, moderate groups inclined to counter them with pluralist and, to some extent, pro-government arguments.
The controversy over blasphemy became a crucial point of debate which differentiates between conservative and moderate factions. Among conservative groups, the statement of Ahok in the Pramuka Island on September 27, 2016, was blasphemy to the Muslim community. It insulted Islam and Ahok should be responsible with his indecent words. Meanwhile, moderate Muslims do not consider it as blasphemy because the context of the statement was criticism to Muslim preachers who used the verse of Al-Maidah 51 to attack Ahok. Also, based on the two-thirds of 35 expert opinion, there was no indication that Ahok's words are expressing blasphemy [5].

While conservative Muslims believe that the interpretation of 'Al-Maidah 51' is a convincing text forbidding Muslims to elect a non-Muslim leader, moderate Muslims have a different opinion. One of the moderate ulama, Ahmad Ishomudin, argued that the verse does not talk about the formal leader as presumed by some people. It talks about Jews and Christian groups who against the prophet under the war situation and Muslims are not allowed to collaborate with them as friends (political alliance). Ishomudin found that it has nothing to do with electing a formal leader, let alone the governor [6].

Regarding religious edict (fatwa), moderate Muslims also have an interesting perspective. According to MUI's opinion, Ahok's statement despised the Qur'an and ulama, so the police should persecute him [7]. Instead of supporting the religious opinion of Indonesia Ulama Council (MUI) which was later on claimed as a fatwa, some moderate Muslims questioned it. Rumadi, one of nahdliyyin (NU) young intellectual questioned that if people defend MUI's fatwa, why do they defend only Ahok's case? Whereas MUI has so many fatwa such as prohibition to perform a transaction in conventional banks. Why they do not create a defender group of such a fatwa and close all conventional bank because they are all usury-based institutions. At this point, Rumadi believes that the Muslim movement is not purely religion. It is a political movement using religious sentiments as one of the important factors to draw people's emotion [8].

\section{JOKOWI'S POLICY TO CONSERVATIVE-ISLAMIST GROUPS}

Mass movement using religious sentiments frequently lasted during the Jakarta's election. Since the Ahok blasphemy allegations have emerged in public, the coalition of conservative-Islamist groups staged demonstrations in Jakarta's Central Park (Monas, Monumen National) in October 14th, November 4th and massively in December 2nd, 2016. They named their action with 'Aksi Bela Islam' (Defending Islam Action) whose aspiration was to force the government and law enforcement authorities to prosecute Ahok and put him in jail. From the 'Aksi Bela Islam' part one, two and three, their mass mobilization gained support from congregation of Friday prayer, either from Istiqlal mosque or other mosques.

The Muslim pressure through this mass mobilization drew attention to Jokowi in the 'Aksi Bela Islam' part three, which is known as '212 action' (December 2nd). In the middle of 
500.000 people who gathered for Friday Prayer in Monas, Jokowi came to the crowd under the heavy rain. He joined the prayer and addressed the crowd to thank for their prayer and appreciate those who involved in the event peacefully. According to Fealy, Jokowi's decision to meet the crowd leant his credibility and at the same time, empowered his enemies [5]. However, this surprising event was responded positively by many people. A political observer argues that Jokowi demonstrated a good example of wise president by forgetting different opinion with his people. He proved to be president for all, not only for those who elected him, but also for those who did not [9].

The reaction of Jokowi's regime to the conservativeIslamist pressure seemingly harsh enough although in public he shows his best smile. "I wonder why Jakarta's problem has been shifted to me? It does not make any sense. But I've just smiled to such an irrational movement", Jokowi once said [10]. $\mathrm{He}$, later on, took action by giving "some lessons" to those who dare to challenge him. Riziq Shihab, a leader of FPI and became the central figure in the 'Aksi Bela Islam', has been interrogated by police for pornography allegation and six other cases. However, he ran away to Saudi Arabia on the pretext of doing pilgrimage (umrah) [11]. Some Islamist figures have been charged as the actor of subversion such as Al-Khattath (Leader of FUI/Muslim Forum) and some other activists. The element of Hizbut Tahrir Indonesia (HTI), which intensely involved in many actions, has been dissolved by Jokowi's administration [12].

Although the hurly-burly of Jakarta's election has dragged and disadvantaged Jokowi's administration, it has been a crucial opportunity for Jokowi to sweep any social and political forces whose vision and agenda contravene Indonesia's plural and multicultural ideology. The previous president, Susilo Bambang Yudhoyono, failed to maintain Indonesia from religious intolerance and violence [13]. As a result, conservative and radical factions found their playground and gained many followers and sympathizers from time to time. They used a momentum in the populist agenda as found in the 'Aksi Bela Islam'. Before those destructive forces dominate public life, law enforcement and counter radicalism are seemingly needed in Jokowi's regime.

\section{ACKNOWLEDGEMENT}

This research enables to be written for help and involvement of many people and institutions. I would like to thank director, colleague, and students of Graduate Program of Islam Nusantara, UNUSIA Jakarta. Without their support, this research would be merely a bunch of data that is scattered and silent. I also thank civitas academics of Faculty of Social and Political Science (FISIP) UIN Syarif Hidayatullah Jakarta who has facilitated and encouraged me to submit this paper. May Allah swt award those people with a great virtue and blessing with a more noble reward.

\section{References}

[1] Ahmad Khadafi, Faktor Agama Menentukan Kemenangan Anies-Sandiaga, 20 April, 2017 https://tirto.id/faktor-agamamenentukan-kemenangan-anies-sandiaga-cm79

[2] Yenni Kwok, "Conservative Islam Has Scored a Disquieting Victory in Indonesia's Normally Secular Politics," April 20, 2017. http://time.com/4747709/indonesia-jakarta-electiongovernor-islam-christianity-ahok-anies/

[3] Fakta Tentang Jenazah Hindun yang Tak Disalatkan di Mushola, Tempo Magazine, 11 March 2017. https://m.tempo.co/read/news/2017/03/11/214855038/faktatentang-jenazah-hindun-yang-tak-disalatkan-di-mushola

[4] Greg Fealy, "A Conservative Turn", Inside Indonesia, 15 July 2007; Martin van Bruinessen, Introduction: Contemporary Developments in Indonesian Islam and the Conservative Turn of the early twenty-first century, in Contemporary Development in Indonesian Islam: Explaining the Conservative Turn, ISEAS, Singapore, 2013, p.3.

[5] Greg Fealy, "Bigger than Ahok: Explaining the 2 December Mass Rally", Indonesia at Melbourne, 05 December 2016. http://indonesiaatmelbourne.unimelb.edu.au/bigger-than-ahokexplaining-jakartas-2-december-mass-rally/

[6] PBNU: Muslim dan Non-Muslim Berhak Jadi Pemimpin, Kompas,

10/10/2016.http://megapolitan.kompas.com/read/2016/10/10/07 394221/pbnu.muslim.dan.non-muslim.berhak.jadi.pemimpin

[7] MUI Nilai Kutipan Ahok tentang surah Al Maidah hina Alquran \& ulama, Merdeka, 12 October 2016. https://www.merdeka.com/peristiwa/mui-nilai-kutipan-ahoktentang-surah-al-maidah-hina-alquran-ulama.html

[8] Kenapa sibuk dengan fatwa MUI tertentu tapi tak pusing dengan fatwa lain? BBC Indonesia, 18 January 2017. http://www.bbc.com/indonesia/indonesia-38647137

[9] Tamrin Amal Tamagola, "Presiden di Tengah Aksi Damai", $\begin{array}{llll}\text { Metro } T V, & \text { December }\end{array}$ https://www.youtube.com/watch?v=IM_lwAEYbbk

[10] Jokowi: Saya Heran, Ini Urusan DKI Kok Digeser ke Presiden, Kompas.com, 13/11/2016. http://nasional.kompas.com/read/2016/11/13/18525761/jokowi. saya.heran.ini.urusan.dki.kok.digeser.ke.presiden

[11] Tujuh perkara pidana yang membelit Rizieq Shihab, BBC.com, 16 May 2017,http://www.bbc.com/indonesia/indonesia39931546

[12] HTI Resmi Dibubarkan Pemerintah, Kompas.com, 19/07/2017.http://nasional.kompas.com/read/2017/07/19/10180 761/hti-resmi-dibubarkan-pemerintah

[13] Robin Bush, 'Religious Politics and Minority Rights During the Yudhoyono Presidency,' in Edward Aspinall, The Yudhoyono Presidency: Indonesia's Decade of Stability and Stagnation, ISEAS, Singapore, 2015. 